\section{By-Products of a Former Phenol Manufacturing Site in a Small Lake Adjacent to a Superfund Site in the Aberjona Watershed}

\section{Lukas Y. Wick* and Philip M. Gschwend \\ Ralph M. Parsons Laboratory, Massachusetts Institute of Technology, Cambridge, Massachusetts}

Benzene, diphenyl sulfone (DPS), parahydroxybiphenyl (PPP), ortho-hydroxybiphenyl (OPP), higher hydroxybiphenyls, and alkylated benzenes were found in a small lake receiving contaminated groundwater discharge from the Industri-Plex Superfund site (Woburn, MA) in the Aberjona watershed in eastern Massachusetts. All of these chemicals may derive from the former phenol manufacturing activities present at the Industri-Plex site during World War I. Concentrations up to $1660 \mu \mathrm{g} / \mathrm{l}$ benzene, $450 \mu \mathrm{g} / \mathrm{DPS}, 230 \mu \mathrm{g} / \mathrm{PPP}$, and $100 \mu \mathrm{g} / \mathrm{OPP}$ were detected in the hypolimnion. Epilimnetic concentrations of the chemicals were significantly lower (normally $<5 \mu \mathrm{g} /$ ). DPS showed a distinct seasonal behavior: It was readily biodegradable during warm periods. No biodegradation was observed in the winter, leaving export to the Aberjona River as the major removal mechanism. Although benzene is known to be toxic and a human carcinogen, our results indicate that DPS, OPP, and PPP are not mutagenic in tests using human MCL-5 and h1A1v2 cell lines. - Environ Health Perspect 106(Suppl 4):1069-1074 (1998). http://ehpnet1.niehs.nih.gov/docs/1998/Supp/-4/1069-1074wick/abstract.htm/

Key words: benzene, diphenyl sulfone, ortho-hydroxybiphenyl, para-hydroxybiphenyl, phenol manufacture, explosives, mutagenicity, Aberjona

\section{Introduction}

Many hazardous waste sites are located close to surface water bodies. Discharge of contaminated groundwater from these sites, with subsequent transport of potentially toxic chemicals to downstream receptors, is therefore likely to occur. Knowledge of the environmental fates and toxicities of the chemicals is crucial to anticipate the impact of these pollutants. In an effort to assess such chemical impacts, we have been examining the inputs and dynamic behaviors of organic chemicals in the Halls Brook Holding Area ([HBHA]; Woburn, MA) in yearround studies.

HBHA is a small lake in the Aberjona watershed in eastern Massachusetts. HBHA receives groundwater input from an adjacent Superfund site (Industri-Plex). Industri-Plex is a former industrial area with a long history (1853-1967) of manufacturing organic and
This paper is based on a presentation at the Symposium on the Superfund Basic Research Program: A Decade of Improving Health through Multi-Disciplinary Research held 23-26 February 1997 in Chapel Hill, North Carolina. Manuscript received at EHP 11 December 1997; accepted 21 April 1998.

Financial support for this work by the Swiss National Science Foundation, the Ciba-Geigy Jubiläumsstiftung, and National Institute of Environmental Health Sciences Superfund Basic Research Program grants P42ES04675-09 and National Institutes of Health-5-P42-ES04675-10 is gratefully acknowledged. Many thanks to E. Medilanski and M. Rojo for analysis of the volatile organic compounds. The authors also wish to thank the Center for Environmental Health Sciences at the Massachusetts Insitute of Technology for financial support for the mutagenicity tests, Gentest Corporation (Woburn, MA) for the performance of the human cell mutation assays, and B. Penman (Gentest) for discussion of the mutagenicity results. We also thank Digital Equipment Corporation for access to the Industri-Plex site.

Address correspondence to P. Gschwend, Ralph M. Parsons Laboratory, 48-415, Massachusetts Institute of Technology, Cambridge, MA 02139. Telephone: (617) 253-1638. Fax (617) 253-7395. E-mail: pmgschwe@mit.edu

*Present address: Swiss Federal Institute for Environmental Science and Technology (EAWAG), Uberlandstrasse 133, CH-8600 Dubendorf, Switzerland.

Abbreviations used: BTEX, benzene, toluene, ethylbenzene, xylenes; DCM, dichloromethane; DPS, diphenyl sulfone; DHBP, 2,2'-dihydroxybiphenyl; GC, gas chromatography; HBHA, Halls Brook Holding Area; MPP, meta phenylphenol; OPP, ortho-phenylphenol; PPP, para-phenylphenol; t, metric ton; T, temperature; tk, thymidine kinase; VOC, volatile organic compound. inorganic chemicals (1). The Aberjona watershed, located in the northern suburbs of Boston, was once a major center for leather tanning and chemical manufacture (2). It contains two Superfund sites and numerous identified hazardous waste sites. Several studies on potential health effects in the watershed have been performed (3-6). In Woburn, one community of the Aberjona watershed, a childhood leukemia rate 4 -fold above the national average was observed between 1966 and 1986 (7). This fact has been related to the consumption of contaminated drinking water pumped from wells $\mathrm{G}$ and $\mathrm{H}$ within the watershed south of the HBHA (3).

Benzene, diphenyl sulfone (DPS), $p$-hydroxybiphenyl (also called p-phenylphenol [PPP]), and $o$-hydroxybiphenyl (also called ortho-phenylphenol [OPP]), among other higher phenols and solvents, were identified as some of the major volatile and semivolatile organic compounds in the HBHA (8). All of these pollutants may derive from the WW I-era manufacture process of phenol on the site (8). Phenol, the first aromatic chemical synthesized on a large scale in the United States (9), was a common disinfectant and starting material for the synthesis of dyes and explosive intermediates (picric acid). Here we report on the occurrence of these waste products of the manufacture of phenol and their distribution in an adjacent lake (the $\mathrm{HBHA}$ ) receiving groundwater discharge from the former manufacturing site. The importance of recognizing the seasonally changing fate of a pollutant, and the consequences for temporally varying transport to downstream receptors, is exemplified in this paper with DPS.

Many studies on the toxicity and mutagenicity of benzene (10) and OPP have been conducted (11). Whereas benzene is toxic and a known human carcinogen (10), OPP is of low toxicity and experimental data are inadequate to evaluate OPP as a mutagen $(11,12)$. Only a few studies on the toxicity of DPS and PPP are known $(13,14)$. DPS and PPP have low toxicity for rats or mice (13). In 1991 the U.S. Environmental Protection Agency recommended further study of the toxicologic effects of sulfones (15). PPP and OPP, among other hydroxy biphenyls, are known estrogenic compounds (endocrine disruptors) $(16,17)$. No data on the mutagenicity of DPS, and only data about OPP and PPP based on studies involving bacteria and/or 
nonhuman mammalian (rodent) bioassays, are reported in literature $(11,13)$. To screen for these chemicals' toxicities and mutagenic activities, DPS, OPP, and PPP were tested in a human cell mutation assay $(15,16)$. Briefly, this assay involves the use of B-lymphoblast cell lines $(18,19)$. The h1A1v2 cells constitutively express the cytochrome P4501A1, which is necessary for the metabolism of many promutagens. The MCL-5 cell line, however, has been modified to express a complement of five human cytochrome P450 oxygenases (CYP1A1, CYP1A2, CYP2A6, CYP2E1, CYP3A4) and microsomal epoxide hydrolase. By combining this group of enzymes in the human cell culture used for chemical screening, the likelihood of recognizing the mutagenicities of particular test compounds requiring activation before acting as mutagens is enhanced.

\section{Materials and Methods}

\section{Site Description}

The HBHA is a small, shallow, $0.17-\mathrm{km}^{2}$, $40,000-\mathrm{m}^{3}$ lake in the Aberjona watershed located immediately to the south of Industri-Plex (Figure 1). This lake receives groundwater, about $100 \mathrm{~m}^{3} /$ day (8), from the nearby Industri-Plex Superfund site. The surface water receives inflow from

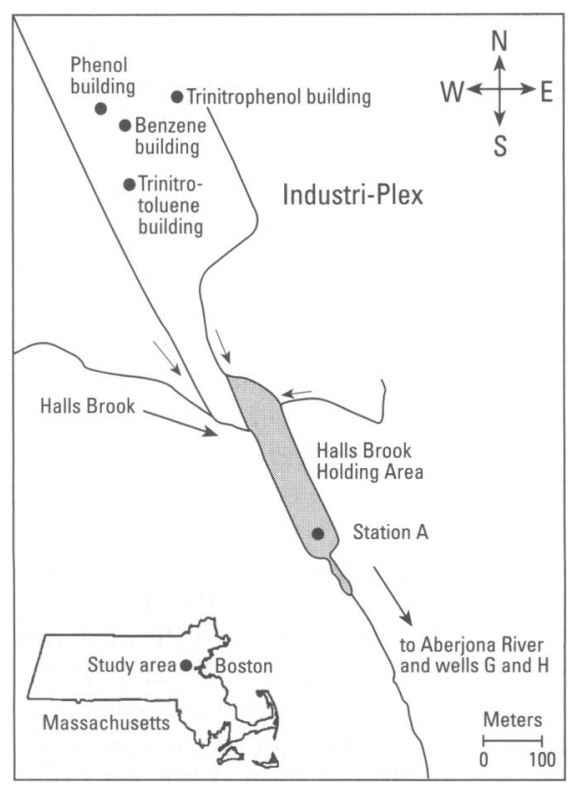

Figure 1. Map of the Halls Brook Holding Area in Woburn, MA and parts of the Industri-Plex Superfund site. Locations of the distillation of benzene and the manufacture of phenol and explosives during World War I (10) are also shown.
Halls Brook, and the outflow empties into an elongated marsh and from there into the Aberjona River. Surface water samples of the Aberjona River were taken on four different days (20 January, 9 February, 29 February, 16 March) during the winter of 1996 about $2.2 \mathrm{~km}$ downstream of the outflow of the HBHA at the Salem Street Bridge in Woburn.

\section{Sampling and Analysis}

Detailed descriptions of most of the methods are given by Wick and Gschwend ( 8 ). Briefly, lake data and water samples were taken monthly year-round. The deep-water samples were pumped at the deepest point of the lake (Figure 1, station A) from approximately $20 \mathrm{~cm}$ above the sediment, and surface water samples were taken from about 5 to $10 \mathrm{~cm}$ below the water surface. These samples were then extracted with dichloromethane (DCM) and analyzed with gas chromatography (GC) using $d_{14}$ $p$-terphenyl and/or $p$-chlorodiphenylsulfone as spiking standards. The unknown compounds were identified by comparisons to $\mathrm{GC}$ retention times and mass spectra we obtained for authentic standards. For the analysis of volatile organic compounds (VOCs), samples were concentrated with a Tekmar LSC2000 purge and trap concentrator using a Tenax/silica gel/charcoal trap. A Carlo Erba HRGC (high resolution gas chromatograph) 5160 (Carlo Erba, Milan, Italy) equipped with a $75-\mathrm{m}, 1-\mu \mathrm{m}$ film thickness, DB5 capillary column ( $5 \%$ phenylmethylpolysiloxane; J\&W Scientific, Folsom, CA) was used. 1,4-Bromofluorobenzene was used in all VOC analyses as an internal standard. Benzene was identified by GC retention times and GC-mass spectroscopy (Hewlett-Packard 5995B; Hewlett-Packard, Palo Alto, CA). Toluene, ethylbenzene, and the xylenes were identified by coelution and comparison of retention times on GC.

Biodegradation experiments were performed with oxic surface water at all seasons (8). Summer (6 August 1995; water temperature $\left.[\mathrm{T}]=23^{\circ} \mathrm{C}\right)$ and spring $(28$ April 1996; water $\mathrm{T}=13^{\circ} \mathrm{C}$ ) water samples were spiked with about 5 to $10 \mu \mathrm{g} / \mathrm{l} \mathrm{DPS}$ using a minimal volume of DCM as solvent. For the measurements in the fall (24 October 1995; water $\mathrm{T}=14^{\circ} \mathrm{C}$ ) and winter (29 February 1996; water $\mathrm{T}=5.5^{\circ} \mathrm{C}$ ), no spikes were added. A biodegradation experiment with anoxic (oxygen content $<60 \mathrm{ppb}$ ) hypolimnetic water (water $\mathrm{T}=12^{\circ} \mathrm{C}$ ) was performed on 24 November $1995(8)$.

\section{Mutagenicity Tests}

DPS, OPP, and PPP were tested for their mutagenic activity at the thymidine kinase (tk) locus in MCL-5 and h1A1v2 cell lines derived from human B-lymphoblastoid cells as described by others (20). All testing was performed by Gentest Corporation (Woburn, MA). The individual compounds dissolved in dimethyl sulfoxide were tested with about $1.8 \times 10^{6}$ cells $/ 12 \mathrm{ml}$ replicate culture with an exposure time of $72 \mathrm{hr}$. The test concentrations used were $0.01,0.1,1.0$, and $10 \mu \mathrm{g} / \mathrm{ml}$ for the hydroxybiphenyls (OPP, PPP) and $0.1,1.0$, and $10 \mu \mathrm{g} / \mathrm{ml}$ for DPS (i.e., at chemical activities near $10^{-5}$ or less.) We note that the activities of the chemicals in the waters flowing south out of the HBHA were typically $10^{-5}$ or less (defined as the ratio of a compound's concentration in the water to its subcooled liquid solubility). The mean mutant fraction of each test was compared to the concurrent (Dunnett's $t$ test, $p=0.05$ ) and historical negative control observations. Toxicity (survival rates) was determined as the ratio of surviving treated cells to surviving negative control cells measured from the beginning of treatment until plating.

\section{Results and Discussion}

\section{Production of Phenol on the Industri-Plex Site}

During World War I, large amounts of benzene $(21)$, phenol $(8,22,23)$, and explosives $(2,4,6$-trinitrophenol [picric acid], 2,4,6-trinitrotoluene) were produced $(22,24)$ on the Industri-Plex site by the New England Manufacturing Company (Woburn, MA) (22). No actual phenol production data of the New England Manufacturing Company are available. Estimates based on U.S. phenol production data, however, suggest that between 1915 and 1918 about 2 to $5 \%$ of the national phenol production, amounting to 5000 to 12,000 metric tons $(t)$, was manufactured on the site. This would have resulted in the use of at least 8000 to $21,000 \mathrm{t}$ crude benzene, assuming an overall yield of the phenol manufacture of 60 to $65 \%$ (8). Approximately 100 to $300 \mathrm{t}$ DPS and 80 to 210 t hydroxybiphenyls (OPP, PPP) were likely produced during these processes $(8)$.

\section{By-Products of the Manufacture Process to Phenol and Picric Acid}

Starting from crude benzene, the manufacture of phenol (sulfonic acid route) was a multistep process. Crude benzene was 
recovered from coke oven gas (light oil). The refining process of crude benzene normally consisted of two distinct operations: treatment of the crude benzene with concentrated $(93 \%)$ sulfuric acid and fractional distillation of the acid-treated crude (25). Toluene, ethylbenzene, and xylenes are common contaminants in crude benzene and by-products of the refining process (26). Benzene was then converted to benzenesulfonic acid, which was treated with $\mathrm{NaOH}$ to give crude phenol (Figure 2 ). Crude phenol was purified by distillation. DPS is a by-product of the sulfonation; OPP and PPP, among other hydroxybiphenyls (e.g., meta-phenylphenol [MPP] and 2,2'-dihydroxybiphenyl [DHBP]) are side products of the conversion of the benzenesulfonic acid to phenol with caustic soda (8). High loads of inorganic salts $\left(\mathrm{Na}_{2} \mathrm{SO}_{3}\right.$ and $\left.\mathrm{Na}_{2} \mathrm{SO}_{4}\right)$ are also to be expected using this process (27). The hypolimnetic water had $\mathrm{Na}^{+}$and $\mathrm{SO}_{4}{ }^{2-}$ as the major ionic species with typical concentrations of approximately 17 and $11 \mathrm{mM}$.

A significant fraction of the phenol produced by the New England Manufacturing Company was used in the manufacture of explosives on the site. Phenol was converted to picric acid through sulfonation and subsequent nitration of the disulfonated phenol (Figure 2) (28). As in the production of phenol, other and still unidentified by-products can be expected from the manufacture of explosives on the site because recoveries of the war-driven manufacture of picric acid normally did not exceed $80 \%(28)$.

\section{Presence and Distribution of BTEX, DPS, OPP, and PPP in the HBHA}

Benzene, toluene, ethylbenzene, and xylenes (BTEX), DPS, OPP, and PPP enter the HBHA with the groundwater. The concentrations of BTEX, DPS, OPP, and PPP in the surface water inflow (Halls Brook) were consistently below $1 \mu \mathrm{g} / \mathrm{l}$ or were not detectable (detection limit $<0.1$ $\mu \mathrm{g} / \mathrm{l})$. Because of the high salinity of the groundwater discharge, the HBHA was stratified year-round, with typical values of about $2500 \mu \mathrm{mho} / \mathrm{cm}$ in the hypolimnion and about $400 \mu \mathrm{mho} / \mathrm{cm}$ in the epilimnion (Figure 3 ). A sharp separation into an oxic epilimnion and an anoxic hypolimnion was usually observed. Concentrations of BTEX, DPS, OPP, and PPP were therefore always considerably higher in the hypolimnion than in epilimnion. The chemicals' profiles normally

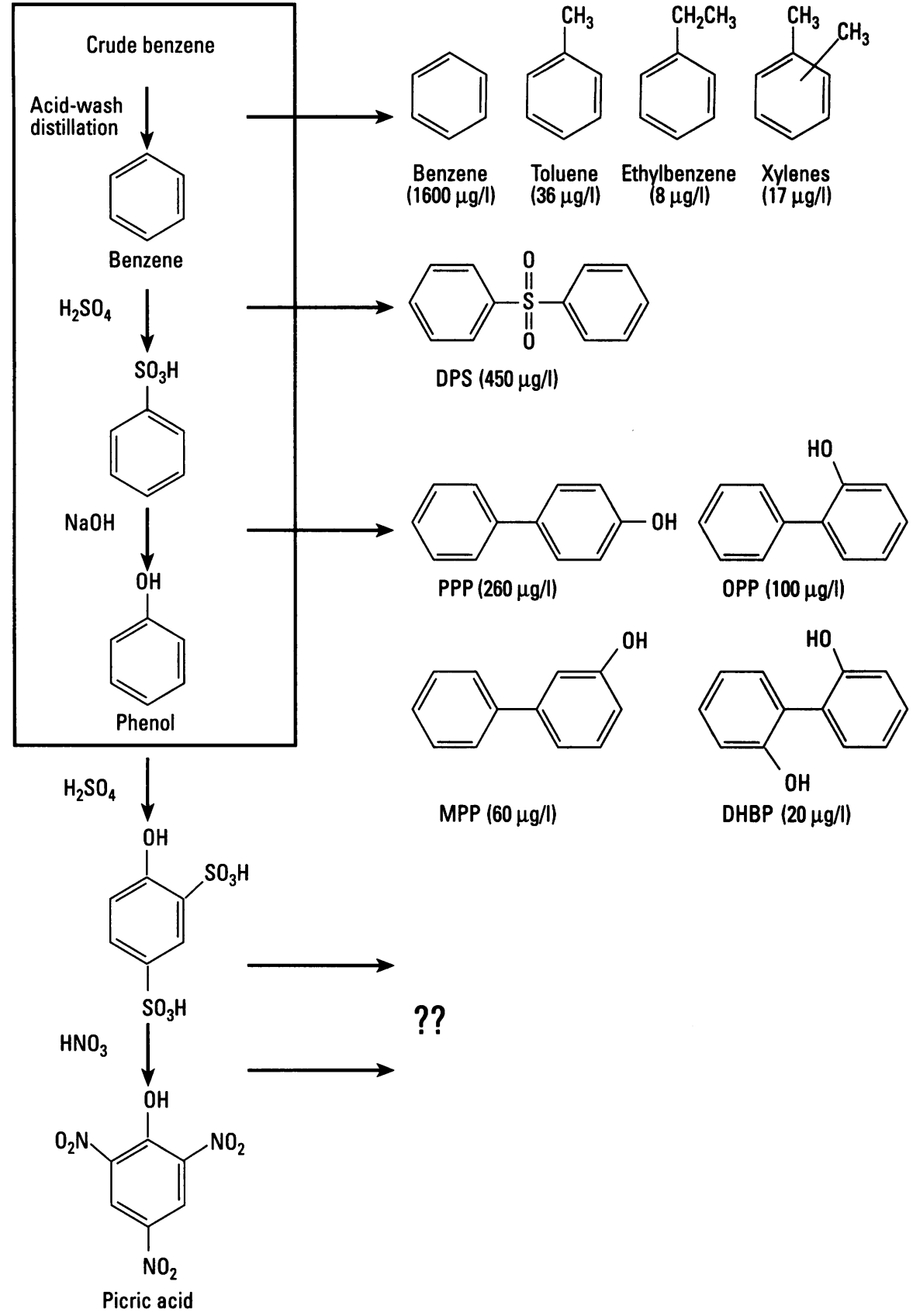

Figure 2. Identified by-products (benzene, toluene, ethylbenzene, and xylenes, DPS, OPP, PPP, MPP, and DHBP) of the sulfonic acid method manufacturing pathway to phenol and its conversion to picric acid in the Halls Brook Holding Area. Values in parentheses are the chemicals' highest concentrations found in the hypolimnion. Question marks indicate that a variety of still-unidentified side products of the manufacture of picric acid can be expected.

followed the conductivity profiles, with mixing processes responsible for the chemicals' input into the epilimnion. An unexplained increase of the DPS concentration at the pycnocline was sometimes observed in the summer (Figure 3). This may be due to an isopycnal mixing of groundwater seepage of high DPS concentration but lower salinity. In the hypolimnion, concentrations of 80 to $450 \mu \mathrm{g} / \mathrm{l} \mathrm{DPS},<0.1$ to $60 \mu \mathrm{g} / \mathrm{l}$ OPP, 50 to $260 \mu \mathrm{g} / \mathrm{l} \mathrm{PPP}$, and up to $1600 \mu \mathrm{g} / \mathrm{l}$ benzene were seen. With an assumed average input of approximately $100 \mathrm{~m}^{3}$ groundwater/day (with average concentrations of about 750,350 , 45 , and $200 \mu \mathrm{g} / \mathrm{l}$ for benzene, DPS, OPP, and PPP, respectively) approximately 27 $\mathrm{kg} /$ year benzene, $13 \mathrm{~kg} /$ year DPS, and 10 $\mathrm{kg} /$ year for the two hydroxybiphenyls are discharged to the lake. DPS values ranged 

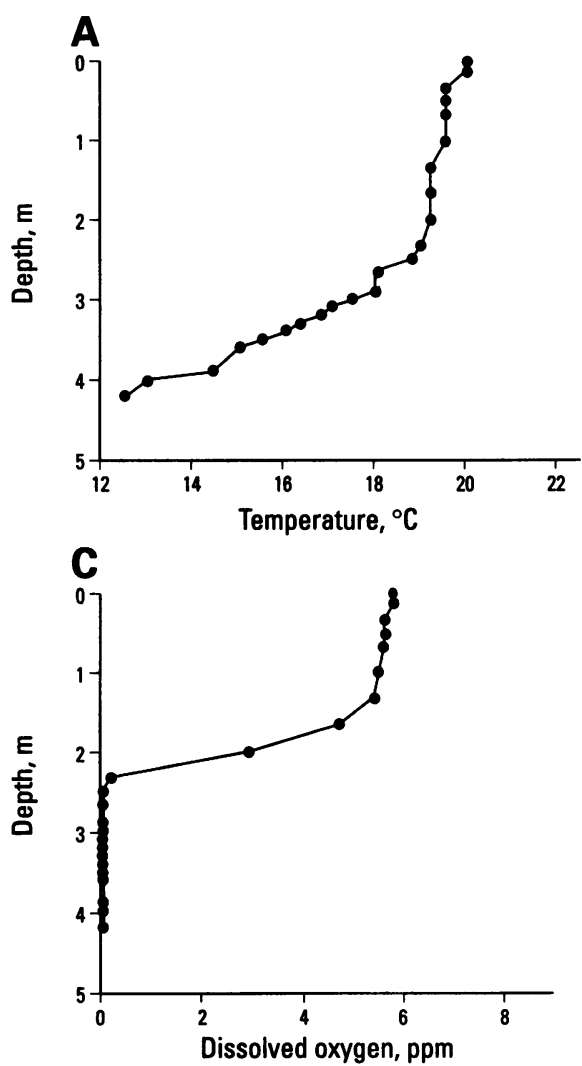
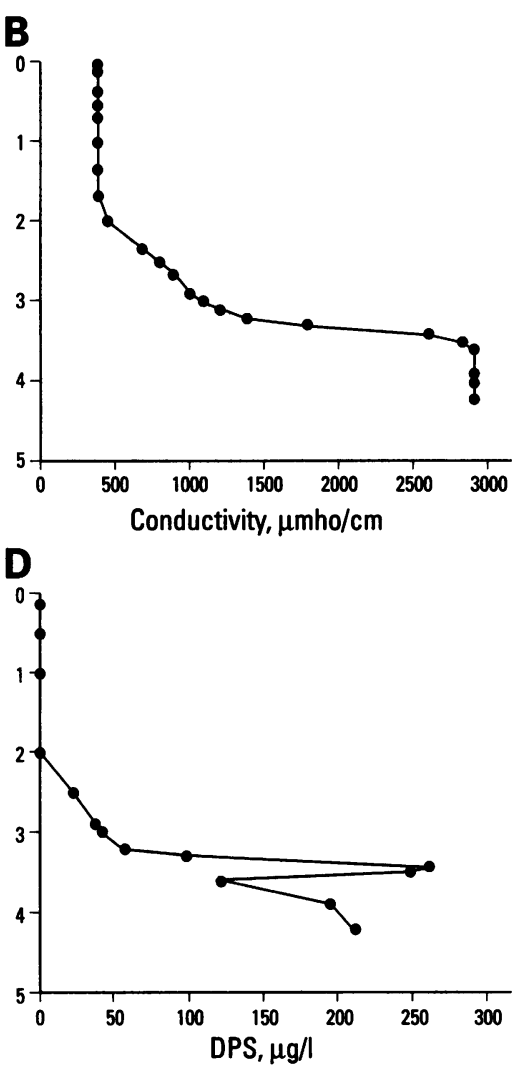

Figure 3. $(A)$ Temperature, $(B)$ conductivity, $(C)$ dissolved oxygen, and $(D)$ diphenyl sulfone profiles on 25 July 1996 at station A, the deepest point of the Halls Brook Holding Area.
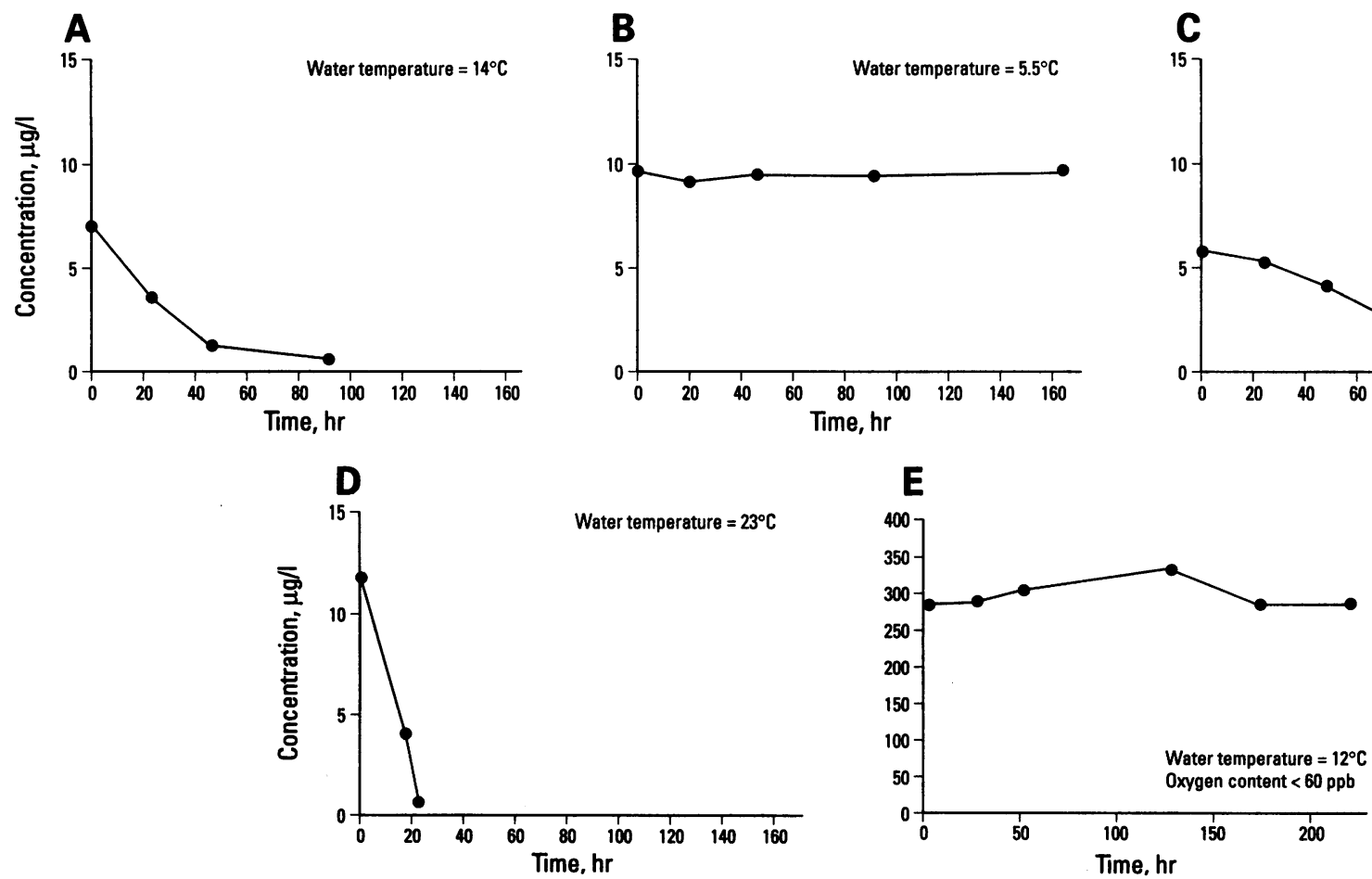

Figure 4. Biodegradation for diphenyl sufone in Halls Brook Holding Area epilimnic water for (A) 24 October 1995 (fall), (B) 29 February 1996 (winter), (C) 28 April 1996 (spring), and (D) 6 August 1996 (summer) conditions. (E) Absence of degradation in anoxic HBHA hypolimnic water collected 8 November 1995 (fall). 
biodegradation experiments (Figure 4); note that the rates mentioned here derive from first-order fits of all of the data, irrespective of possible lag periods. The lag periods may be due to the spiking of the samples. Rate constants for spring and fall are both approximately $0.5 d^{-1}$. Losses in the poisoned control solutions were always negligible $(<10 \%)$.

DPS therefore showed conservative behavior in the winter, leaving flushing as the major removal mechanism with outflow concentrations up to $13 \mu \mathrm{g} / \mathrm{l}$. In the summer, biodegradation was the predominant sink of DPS from the epilimnion of the HBHA. Only low DPS concentrations $(<1 \mu \mathrm{g} / \mathrm{l})$ were observed during the summer, and flushing was much less important than in the cold seasons of the year. For example, measurements of DPS concentrations during the winter at about $2 \mathrm{~km}$ downstream in the Aberjona River (Salem
Street Bridge) showed a persistent presence of DPS during the cold season. Smaller concentrations at the downstream location are due, at least in part, to dilution effects because of the confluence of the outflow water with the Aberjona River (Table 1).

\section{Mutagenicity Testing}

The mutagenicities of DPS, PPP, and OPP were tested at the tk locus in human MCL5 and $\mathrm{h} 1 \mathrm{~A} 2 \mathrm{v} 2$ cell assays. There was no evidence of a mutagenic effect of DPS, OPP, and PPP at the tk locus in either cell line under the conditions of the assay (Figures 5 and 6). In either comparison to the historical negative controls or in comparison to the concurrent negative controls, no response of cultures exposed to any test concentration was significantly different. Additionally, all three chemicals were essentially nontoxic to the cells at the concentrations tested (Figures 5 and 6).
The relative survival rate in both cell lines was in the range of 0.90 to 0.94 for all chemicals at the highest concentration (10 $\mu \mathrm{g} / \mathrm{ml}$ ) tested.

We note, however, that these mutagenicity screening tests do not preclude the possibility that the compounds studied exhibit other modes of toxicity (e.g., endocrine disruption). Further, we have not evaluated the prospects for toxicity to other organisms

Table 1. Diphenyl sulfone concentrations $(\mu \mathrm{g} / \mathrm{l})$ at the outflow of Halls Brook Holding Area and at a downstream location in the Aberjona River (Salem Street Bridge) during winter 1996.

\begin{tabular}{lcccc}
\hline & \multicolumn{4}{c}{ DPS, $\mu \mathrm{g} / \mathrm{l}$} \\
\cline { 2 - 5 } Location & $\begin{array}{c}20 \\
\text { January }\end{array}$ & $\begin{array}{c}9 \\
\text { February }\end{array}$ & $\begin{array}{c}29 \\
\text { February }\end{array}$ & $\begin{array}{c}16 \\
\text { March }\end{array}$ \\
\hline HBHA & 9.5 & 5 & 9 & 8 \\
$\begin{array}{c}\text { Aberjona } \\
\text { River }\end{array}$ & 8 & 2 & 2.5 & 4 \\
\hline
\end{tabular}
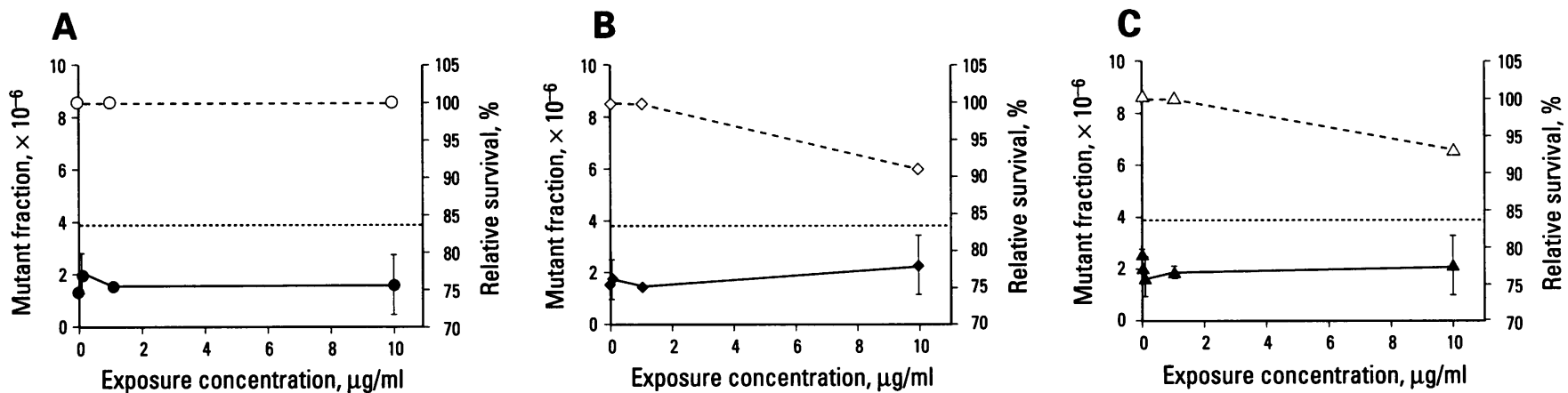

\begin{tabular}{|c|c|c|}
\hline$-\infty-$ Relative survival DPS & $--\diamond-\cdot$ Relative survival PPP & $--\triangle--$ Relative survival OPP \\
\hline$\longrightarrow$ Mutant fraction DPS & $\multimap$ Mutant fraction PPP & $\longrightarrow$ Mutant fraction OPP \\
\hline
\end{tabular}

Figure 5. Toxicity (right $y$-axis) and mutagenicity (left $y$-axis) in h1A1v2 cells induced by a 72-hr exposure to $(A)$ DPS, $(B)$ PPP, and $(C)$ OPP at different concentrations. The horizontal dashed line indicates the $99 \%$ upper confidence limit for the historical negative control and the error bars represent the mean \pm standard deviation.
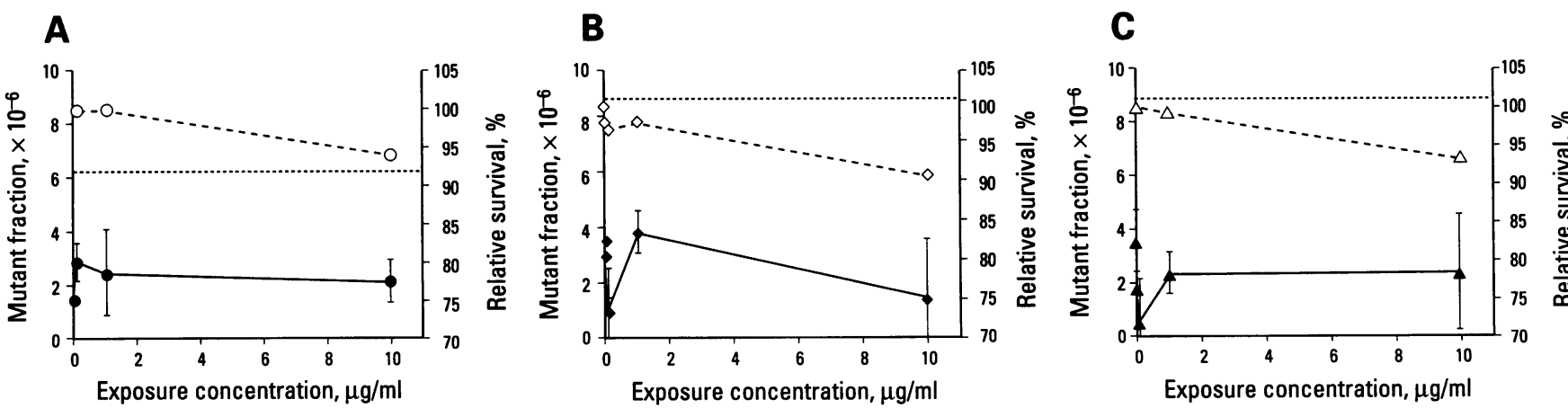

\begin{tabular}{|lll|}
\hline$-\circ--$ Relative survival DPS & $--\diamond-\cdot$ Relative survival PPP & $\cdots--$ Relative survival OPP \\
$\longrightarrow-$ Mutant fraction DPS & $\rightarrow-$ Mutant fraction PPP & - \\
\hline
\end{tabular}

Figure 6. Toxicity (right $y$-axis) and mutagenicity (left $y$-axis) in MCL-5 cells induced by a 72-hr exposure to $(A)$ DPS, $(B)$ PPP, and $(C)$ OPP at different concentrations. The horizontal dashed line indicates the $99 \%$ upper confidence limit for the historical negative control and the error bars represent the mean \pm standard deviation. 
present downstream in the Aberjona River watershed. Finally, our observations of benzene, a known toxic substance, demonstrate that at least some downstream delivery of one hazardous substance occurs from a subsurface waste site via groundwater exfiltration and surface water flow.

\section{Conclusions}

Diphenyl sulfone is most likely stable under anoxic conditions, but it is readily biodegradable under oxic, and especially warm, water temperatures. No biodegradation was observed in the winter, which identified flushing as the major removal mechanism. Because of the year-round stratification, the hypolimnion of HBHA acts as a reservoir of the contaminated groundwater inflow from Industri-Plex. This deep water may be episodically flushed by major storm events (which we did not monitor), resulting in pulses of contamination into the overlaying epilimnion with a subsequent downstream transport. Given the observation that cold water temperatures minimize biodegradation rates, as shown for DPS, such downstream transport may be especially important in the cold season. Such wintertime enhancement of the downstream delivery of normally biodegradable organic compounds may be common.

The presence of benzene, DPS, OPP, PPP, and other possible by-products gives clear evidence of a continued leaching of chemicals from an industrial site even 80 years after the operations (production of phenol) were stopped. Because of the high amounts of organic waste expected to be present at the site, at the current discharges to $\mathrm{HBHA}$, a release of these and other unidentified side products could continue for a long time. Even if DPS, OPP, and PPP are nontoxic and nonmutagenic in our tests, the production of explosives suggests that a variety of other still unidentified and potentially toxic compounds (e.g., side products of the manufacture of explosives and their degradation products) may be flushed out of the HBHA to downstream receptors.

\section{REFERENCES AND NOTES}

1. Aurilio A, Durant JL, Hemond HF, Knox ML. Sources and distribution of arsenic in the Aberjona watershed, eastern Massachusetts. Water Air Soil Pollut 78:1-18 (1994).

2. Durant JL, Zemach JJ, Hemond HF. The history of leather industry waste contamination in the Aberjona watershed: a mass balance approach. Civil Eng Pract Fall:41-66 (1990).

3. Massachusetts Department of Public Health. Woburn Childhood Leukemia Follow-up Study. Boston:Bureau of Environmental Health Assessment, Massachusetts Department of Public Health, 1996.

4. Durant JL, Chen J, Hemond HF, Thilly WG. Elevated incidence of childhood leukemia in Woburn, Massachusetts: NIEHS Superfund Basic Research Program searches for causes. Environ Health Perspect 103 (Suppl 6):93-98 (1995).

5. Durant JL, Hemond HF, Thilly WG. Determination of mutagenicity in sediments of the Aberjona watershed using human lymphoblast and Salmonella typhimurium mutation assays. Environ Sci Technol 26:599-608 (1992).

6. Rogers CE, Tomita AV, Trowbridge PR, Gone JK, Chen J, Zeeb P, Hemond HF, Thilly WG, Olmez I, Durant JL. Hair analysis does not support hypothesized arsenic and chromium exposure from drinking water in Woburn, Massachusetts. Environ Health Perspect 106:1090-1096 (1998).

7. U.S. DHEW. Atlas of Cancer Mortality for U.S. Counties: 1950-1969. Publ No 75-780. Washington:U.S. Department of Health, Education and Welfare.

8. Wick LY, Gschwend PM. Source and chemodynamic behavior of diphenyl sulfone, and ortho- and para-hydroxybiphenyl in a small lake receiving discharges from an adjacent superfund site. Environ Sci Technol 32:1319-1328 (1998).

9. Haynes W. American Chemical Industry. Vol 2. New York:Van Nostrand, 1945;22.

10. Fruscella W. Benzene. In: Encyclopedia of Chemical Technology. Vol 4 (Kirk RE, Othmer DF, eds). New York:The Interscience Encyclopedia, Inc., 1992;73-103.

11. Phenylphenol. Dangerous Properties of Industrial Materials. Report 14 (1):58-70 (1994).

12. IARC. ortho-Phenylphenol and its sodium salts. In: IARC Monographs on the Evaluation of the Carcinogenic Risk of Chemicals to Humans. Vol 30: Miscellaneous Pesticides. Lyon:International Agency for Research on Cancer, 1983;329-344.

13. Richardson ML, Gangolli S, eds. The Dictionary of Substances and Their Effects. London:The Royal Society of Chemistry, 1992.

14. Gunther FA, ed. Residue Reviews. Vol 36. New York:Springer, $1971 ; 244-245$.
15. U.S. Environmental Protection Agency. Twenty-seventh report of the interagency testing committee to the administrator; receipt of report and request for comments regarding priority list of chemicals. Fed Reg 56:9534-9572 (1991).

16. Soto AM, Lin TM, Justicia H, Silvia RM, Sonnenschein C. An "in culture" bioassay to assess the estrogenicity of xenobiotics (E-SCREEN). Adv Mod Environ Toxicol 21:295-309 (1992).

17. Rudel RA, Melly SJ, Geno PW, Sun G, Brody JG. Identification of alkyl phenols and other estrogenic phenolic compounds in waste water, septage, and groundwater on Cape Cod, Massachusetts. Environ Sci Technol 32:861-869 (1998).

18. Crespi CL, Thilly WG. Assay for mutation in human lymphoblastoid line, AHH-1, competent for xenobiotic metabolism. Mutat Res 128:221-230 (1984).

19. Crespi CL, Gonzalez FJ, Steimel DT, Turner TR, Gelboin HV, Penman BW, Langenbach RA. Metabolically competent cell line expressing five cDNAs encoding procarcinogen-activating enzymes: application to mutagenicity testing. Chem Res Toxicol 4:566-572 (1991).

20. Busby WFJ, Penman BW, Crespi CL. Human cell mutagenicity of mono- and dinitropyrenes in metabolically competent MCL-5 cells. Mutat Res 322:233-242 (1994).

21. Sandborn Fire Insurance Company. Sandborn Fire Insurance Map of the City of Woburn. New York:Sandborn Fire Insurance Company, 1918.

22. Haynes W. Chemical Pioneers. Vol 3. New York:Van Nostrand, 1939;71.

23. Merrimac Chemical Company. Process of Making Phenols, U.S. Patent No 1245353. Boston:Merrimac Chemical Company, 1917.

24. F.C. Hart Associates New York. Plan for Investigation of Hazardous Waste Problems: Woburn, Massachusetts Area, 1980. Unpublished data.

25. Kirk RE, Othmer DF, eds. Encyclopedia of Chemical Technology. Vol 2. New York:The Interscience Encyclopedia, Inc., 1953;429-435.

26. Ullmann F, ed. Enzyklopädie der technischen Chemie. Vol 2. Berlin/Wien:Urban \& Schwarzenberg, 1915;362-364.

27. Weissermel K. Arpe HJ. Industrial Organic Chemistry. Weinheim/New York/Basel/Cambridge/Tokyo:Verlag Chemie, $1993 ; 345$.

28. Ullmann F, ed. Enzyklopädie der technischen Chemie. Vol 5. Berlin/Wien:Urban \& Schwarzenberg, 1914;106-107. 